\title{
Potential Plants Developed With Agroforestry System For Forest Land Rehabilitation In East Java
}

\author{
Indah Rekyani Puspitawati ${ }^{1 *}$, Anang Susanto ${ }^{2}$ \\ ${ }^{1,2}$ Departemen of Agricultural Science, of Merdeka University, Jl. Serayu79 \\ Madiun, East of Java,Indonesia \\ ${ }^{*}$ Corresponding author: \\ Email: Asmadiun@yahoo.com
}

\begin{abstract}
.
Activity the clearing of forest areas and the construction of canals in forest areas, causing a drastic decrease in the forest ground water level and forest depth and causing serious impacts on the ecosystem cycle. the system that will be applied will, of course, be closely related to the interests of the owner of land that expects benefits from the rehabilitation activities carried out. This study aims to provide information about the types of plants that have economic value for the community, according to the extreme nature of forest land, and can be mixed with short-lived plants. Several locations showed survival rates above $75 \%$. There were several types of plants, Albizzia,Tectona, Delbegia, Dipterocarpus, and Gmelina, which were recorded to provide good growth values. The role of the community is needed to the maximum in the efforts to rehabilitate forest land, especially in the area of rights and forest land managed by the community and protected/conservation areas where the community has access to it. Agroforestry has excellent potential to be applied on forest slopes. The application of agroforestry on forest slopes opens new paths for more efficient use of forest slopes with more varied results while considering the aspect of sustainability (conservation). The results of observations made in community gardens and forest lands used by the community and literature review on trials of planting plants for rehabilitation and commodity plants that are economically beneficial to the community, it is known that there are at least ten types of plants.
\end{abstract}

Keywords: Rehabilitation,groundwater, public,forest land, economic.

\section{INTRODUCTION}

Forest land management includes the use and protection of forest land. After For a long time, the use of forest land has caused damage to the forest ecosystem. Due to the clearing of forest areas and the construction of canals In forest areas, there is a decrease in forest groundwater level and forest depth significantly drastic and have a severe impact on the ecosystem cycle that has been well maintained and maintained. In efforts to restore forest areas and non-forested areas, many locations have been managed by the community and even exist [1] Which belongs to the people this is also one of the problems related to the rehabilitation system implemented. The selection of plants and systems to be applied in forest management is linked to the interests of the landowners who are expected to benefit from the rehabilitation activities carried out on the land [2]. Agroforestry systems have been known to have advantages as systems 
combine long-lived and valuable forestry crops with short-lived crops grown as a mixture not against the wishes of the landowner. There is a lot of information on the types of crops cultivated on forest land. This is influenced by the agricultural empowerment program, which was very intensive in the past. In contrast, information on species and silvicultural systems for long-lived forestry plant species is minimal and has not been well implemented in the community[3]. For that, in need information about the types of plants that have high value economically for the community following the extreme nature of forest land and can be mixed with short-lived plants[4]. This study aims to provide information about plants that have economic value for the community depending on the complex nature of forest land and can be intercropped with short-term crops. The search for information was carried out through library research and direct observation in the forest areas of East Java.

\section{METHODS}

Study area

The research was conducted in the community forest of Madiun residency ; data collection was carried out in the month of October-November 2021.

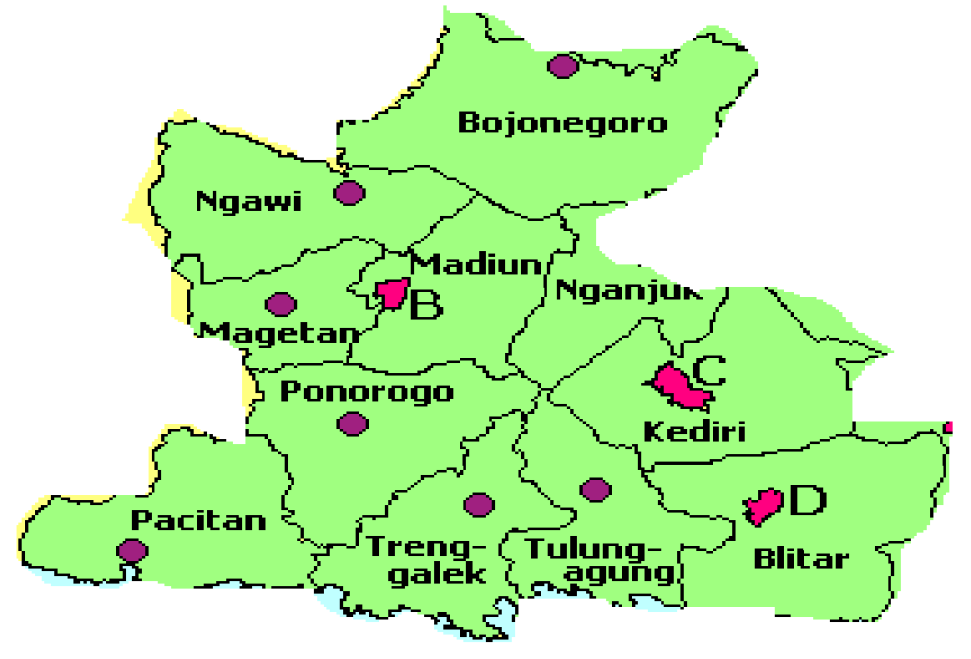

Fig. 1. Study Area - Potential Plants Developed With Agroforestry System

The sampling method used in community forests is stratified random sampling (Strata Sample), a random sampling of areas within a stratified population. The community forest area is then grouped into 3 categories, namely: narrow (area $<0.1$ ha); medium (area between $0.1-0.2 \mathrm{ha}$ ) and wide (area $>2 \mathrm{ha}$ ). For each category, three replicates of community forest samples were taken so that the total number of samples was nine plots. Data collection in the sample plot was carried out with a Sampling Intensity (IS) of $100 \%$. Analysis of the structure of the yard is divided into the horizontal structure and vertical structure. In the horizontal structure, the parameter used is the base area (LBDS). 


\section{RESULT AND DISCUSSION}

Forest land is unique in the form of acidic properties ( $\mathrm{pH}$ or less), nutrient-poor micro and macro and inundated periodically [5]. On forest land degraded by fire, land clearing, and canal construction, pyrite compounds being toxic to plants is also a limiting factor in determining the system rehabilitation on forest land. Moreover, with limited flora, information about the system of silviculture in forest land is still minimal to certain species which have been developed (mostly) in a monoculture

From the results of a 2021 study in East Java, it was noted that there were several rehabilitation locations where the percentage of life was below 50\% [6]. Fires, incompatibility of plant species with limiting factors, seed quality, and minimal maintenance are the dominant causes of the low success of the rehabilitation activities[7]. From several locations that showed survival rates above $75 \%$, several types of plants, Albizzia,Tectona, Delbegia, Dipterocarpus, and Gmelina, were recorded to provide good growth values. Table 1 . Percentage of survival and growth tree years of rehabilitation plants in several locations in EastJava

Table 1. Percentage of survival and growth tree years of rehabilitation.

\begin{tabular}{lllllllll}
\hline No & $\begin{array}{l}\text { Tree } \\
\text { Location }\end{array}$ & $\begin{array}{l}\text { Wide } \\
\text { (Ha) }\end{array}$ & Plant Type & $\begin{array}{l}\text { Planting } \\
\text { Year }\end{array}$ & $\begin{array}{l}\text { Percent } \\
\text { Live(\%) }\end{array}$ & $\begin{array}{l}\text { Plant Growth } \\
\text { Diameter }\end{array}$ & Hight & Description \\
\hline 1 & Maliran & 10 & Albizzia & 2010 & 87,9 & 55,5 & 8,5 & light care \\
\hline 2 & Pare & 10 & Albizzia & 2013 & 91,1 & 32,6 & 7,3 & light care \\
\hline 3 & Kalitidu & 40 & Tectona & 2003 & 92,9 & 31,7 & 8,1 & superior \\
\hline 4 & Panekan & 20 & Albizzia & 2011 & 89,2 & 42,3 & 7,9 & light care \\
\hline 5 & Ngebel & 21 & Swietenia & 2013 & 73,8 & 30,2 & 6,9 & light care \\
\hline 6 & Besole & 16 & Pterocarpus & 2012 & 82,1 & 34,7 & 7,8 & light care \\
\hline 7 & Pogalan & 22 & Delbegia & 2014 & 81,1 & 31,8 & 7,4 & light care \\
\hline 8 & Donorejo & 23 & Gmelina & 2015 & 92,4 & 34,8 & 8,7 & light care \\
\hline
\end{tabular}

source: processed field data 2021

Several locations that showed survival rates above $75 \%$, several types of plants fruit, Artocarpus heterophyllus, Mangifera odorata, Durio zibhethinus, Lansium domesticum, Nephelium lappaceum, and Artocarpus altilis, were recorded to provide good growth values. Table 2. Percentage of survival and growth tree fruit of rehabilitation plants in several locations in East Java 
Table 2. Percentage of survival and growth tree fruit of rehabilitation plants in several locations in East Java

\begin{tabular}{|c|c|c|c|c|c|c|c|c|}
\hline \multirow[b]{2}{*}{ No } & \multirow[b]{2}{*}{$\begin{array}{l}\text { Tree } \\
\text { Location }\end{array}$} & \multirow[b]{2}{*}{$\begin{array}{l}\text { Wide } \\
(\mathrm{Ha})\end{array}$} & \multirow[b]{2}{*}{ Plant Type } & \multirow[b]{2}{*}{$\begin{array}{l}\text { Planting } \\
\text { Year }\end{array}$} & \multirow[b]{2}{*}{$\begin{array}{l}\text { Percent } \\
\text { Live(\%) }\end{array}$} & \multicolumn{2}{|c|}{ Plant Growth } & \multirow[b]{2}{*}{ Description } \\
\hline & & & & & & $\begin{array}{l}\text { Diameter } \\
(\mathrm{cm})\end{array}$ & $\begin{array}{l}\text { Hight } \\
\text { (m) }\end{array}$ & \\
\hline 1 & Maliran & 15 & $\begin{array}{l}\text { Artocarpus } \\
\text { heterophyllus }\end{array}$ & 2012 & 77,9 & 45,7 & 7,7 & light care \\
\hline 2 & Pare & 12 & $\begin{array}{l}\text { Mangifera } \\
\text { odorata }\end{array}$ & 2015 & 81,1 & 31,2 & 6,9 & superior \\
\hline 3 & Kalitidu & 45 & $\begin{array}{l}\text { Artocarpus } \\
\text { heterophyllus }\end{array}$ & 2009 & 82,9 & 41,4 & 7,0 & light care \\
\hline 4 & Panekan & 27 & $\begin{array}{l}\text { Durio } \\
\text { zibhethinus }\end{array}$ & 2001 & 90,2 & 39,1 & 6,4 & $\begin{array}{l}\text { periodic } \\
\text { maintenance }\end{array}$ \\
\hline 5 & Ngebel & 23 & $\begin{array}{l}\text { Lansium } \\
\text { domesticum }\end{array}$ & 2003 & 83,8 & 37,8 & 7,6 & light care \\
\hline 6 & Besole & 46 & $\begin{array}{l}\text { Durio } \\
\text { zibhethinus }\end{array}$ & 2005 & 92,1 & 38,4 & 6,9 & light care \\
\hline 7 & Pogalan & 76 & $\begin{array}{l}\text { Nephelium } \\
\text { lappaceum }\end{array}$ & 2005 & 91,1 & 41,2 & 8,3 & light care \\
\hline 8 & Donorejo & 43 & $\begin{array}{l}\text { Artocarpus } \\
\text { altilis }\end{array}$ & 2004 & 82,4 & 44,9 & 7,6 & light care \\
\hline
\end{tabular}

source: processed field data 2021

Forest land rehabilitation activities, specifically in areas that have property rights status or not property rights but have been managed by the community, is a challenge in itself in its implementation. According to Falah et al. [8], efforts to rehabilitate exproject land Forest Land Development needs to accommodate the interests of the model parties (multi-stakeholder), including the community, government agencies, and local NGOs. This strengthens the option that maximum community participation is required in forest land rehabilitation efforts, especially in the area of rights and forest land managed by the community and conservation protected areas where the community has access. An agroforestry system is one of the land management systems that can be applied for rehabilitation activities in forest land that is in contact with the community. Application This system is expected to link the economic interests of local farmers with the interest of environmental sustainability of forest land [9]

\subsection{Agroforestry system on forest land}

Agroforestry is the name for land-use systems and technologies in which long-lived trees (including shrubs, palms, bamboo, timber, etc.) Short-lived food and fodde shall be cultivated on the same plot of land in a spatial or temporal arrangement. In agroforestry systems, there are interactions ecology and economy between its elements [10]. Agroforestry has excellent potential to be applied to forest slopes. Applying 
agroforestry on forest slopes opens new paths for more efficient use of forest slopes with more mixed results while still paying attention to sustainability (conservation) aspects[11].. Compared to mineral-based agroforestry systems, there is little information on forest lands about sustainable community-adopted agroforestry systems, although this does not mean that there are no agroforestry systems. For example, several Tengger farmers in East Java have developed an intercropping system of rice with fruit trees such as rambutan, mango, and others.

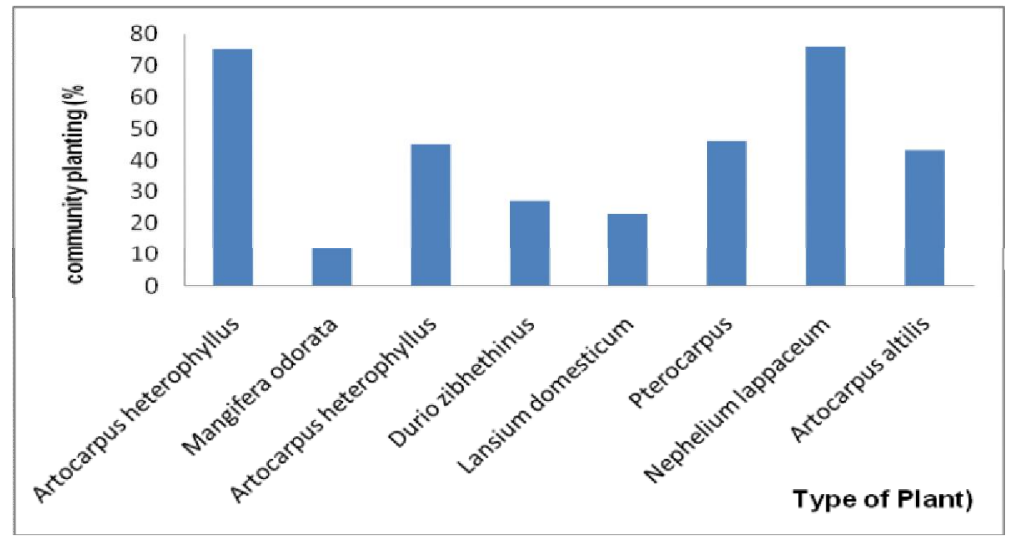

Fig 2. Fruit-producing plants planted by the community

\section{Plant}

Fruits are planted in rice filds which are periodically increase in width. In East Java, especially in watersheds, farmers have developed an agricultural crop rotation system with sengon plants. However, this system still has a monoculture nuance, where pinus plants as the main crop are not mixed with other plants, and the weeding of wild plants is carried out periodically. Communities in East Java are also known to develop a system of sengon gardens, fruit gardens, and fish ponds in forest land for their economic needs.

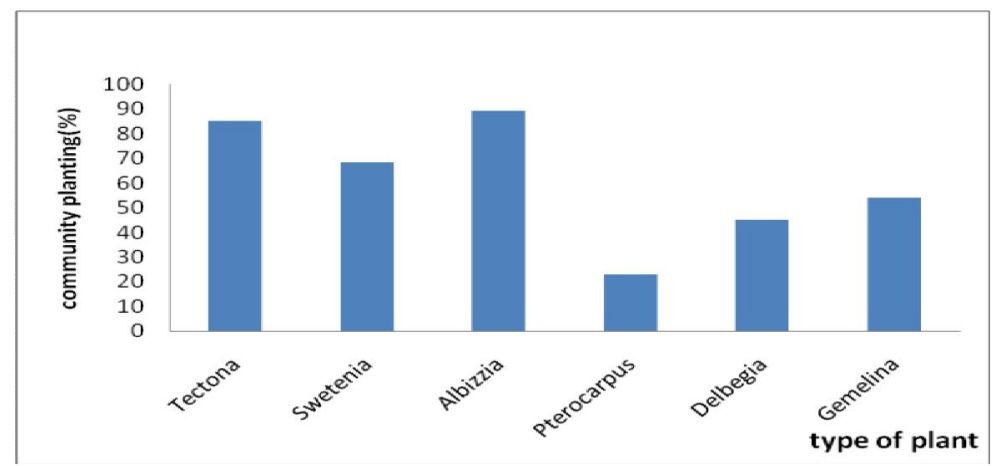

Fig 3. wood-producing plants planted by the community 
Currently, several farmers, both independently and under the guidance of their mentors, have developed agroforestry systems in their forest lands, with the main crops being Albizzia, Tectona, Swetenia, and Delbegia [12].

\section{Potential type}

Avtivity to support the restoration of degraded forest land, the selection of plant species in the agroforestry system is influential. Tolerance to Soil characteristics of the acid forest and periodic flooding with value for community benefits that can be interspersed with short-term crops are essential requirements for the propagation of this species. Based on field observations, especially in community gardens and forest trees used by the community, as well as a literature study on trials of crucial plants that are economically beneficial and restoration for the community, it is known that there are at least 10 types of plants (Table 3). which can be used as the main crop in agroforestry systems to help restore degraded forest land.

Table 3. Potential species as main crops in agroforestry systems for land rehabilitation

\begin{tabular}{llll}
\hline No & Type Tree & utilization & Description \\
\hline 1 & Artocarpus heterophyllus & fruit wood & Moderate Rehabilitation \\
2 & Nephelium lappaceum & fruit wood & Moderate Rehabilitation \\
3 & Artocarpus integer & fruit wood & Moderate Rehabilitation \\
4 & Lansium domesticum & fruit wood & Moderate Rehabilitation \\
5 & Mangifera odorata & fruit wood & Moderate Rehabilitation \\
6 & Mangifera indica & fruit wood & Moderate Rehabilitation \\
7 & Garcinia mangostana & fruit wood & Moderate Rehabilitation \\
8 & Gnetum gnemon & fruit wood & Moderate Rehabilitation \\
9 & Cocos nucifera & fruit wood & Moderate Rehabilitation \\
10 & Aleurites moluccana & fruit wood & Moderate Rehabilitation
\end{tabular}

Score : Sitepu et.al 2011

\section{CONCLUSION}

Development of agroforestry systems can be implemented as one of the efforts rehabilitation of forest land, especially in forest areas with property rights or nonproprietary rights but managed by the community. The selection of agroforestry systems and the main types of crops is based on the resistance to acid, and periodic flooding of forest land has value for the community and can be mixed with short-lived crops. It is known that there are 10 types of plants, native or from outside forest land.

\section{REFERENCES}

[1] Caron BO, Pinheiro MVM, Korcelski C, Schwerz F, Elli EF, Sgarbossa J, Tibolla LB. . Agroforestry systems and understory harvest management: the impact on growth and 
productivity of dual-purpose wheat. Anais da Academia Brasileira de 91 2019,(4). DOI: 10.1590/0001-3765201920180667.

[2] Dewi N, Wijayanto N, Gusmaini. 2017. Dimension growth of Azadirachta excelsa and Phyllabthus spp. in agroforestry system. Biodiversitas 18 2017(2): 494-499. DOI: 10.13057/biodiv/d180207N.

[3] Hairmansis A. Yullianida, Supartopo, Jamil A, Suwarno. Variability of upland rice genotypes response to low light intensity. Biodiversitas 182017 (3): 1122-1129. DOI: 10.13057/biodiv/d180333.

[4] Juliarti A, Wijayanto N, Mansur I, Trikoesoemaningtyas. 2021. The growth of lemongrass (Cymbopogon nardus (L.) Rendle) in agroforestry and monoculture system on post-coal mining revegetation land. Jurnal Manajemen Hutan Tropika 272021 (1): 15-23. DOI: 10.7226/jtfm.27.1.15.

[5] Nugroho AW, Widuri SA, Sayektiningsih T. 2018. Earthworm population at the post coal mining field in East Kalimantan Indonesia. Indonesia J For Res 52018 (2): 81-93. DOI: 10.20886/ijfr.2018.5.2.81-93

[6] Sitepu, B.S., Suhardi, Ermansyah. 2011. Keberhasilan pertumbuhan tanaman di areal rehabilitasi lahan hutan di Jawa Timur. Laporan Hasil Penelitian. Balai Peneltitian Teknologi Konservasi Sumber Daya Alam .2011, pp. 15-42.

[7] Harun, Marinus Kristiadi. 2011. Analisis pengembangan jelutung dengan sistem agroforestri untuk memulihkan lahan hutan terdegradasi di provinsi Jawa Timur. Tesis. Institut Pertanian Bogor. Bogor. 2011 pp. 73-82.

[8] Falah, Faiqotul, Wahyu Catur Adinugroho, Suhardi, Hari Hadiwibowo. 2004. Kajian Teknologi dan Kelembagaan Rehabilitasi Lahan Hutan dengan Pola Perhutanan Sosial di Kawasan Eks PLG, Jawa Timur. Laporan Hasil Penelitian. Loka Litbang Satwa Primata,2004., pp. 30-32.

[9] Nuraida WO, Pradipta P, Suliartini NWS, Wijayanto T, Muhidin, Sadimantara GR. 2020. Production and quality of upland red rice under the shade stress. International Journal of Scientific \& Technology Research 92020 pp. 20-22 (3): 5016-5019.

[10] De Foresta, H., A. Kusworo, G. Michon dan W.A. Djatmiko. 2000. Ketika kebun berupa hutan - Agroforest Khas Indonesia- sebuah sumbangan masyarakat. ICRAF.Bogor. 2020, pp. 81-91.

[11] Lisnawati A, Lahjie AM, Simarangkir BDAS, Yusuf S, Ruslim Y. 2017. Agroforestry system biodiversity of Arabica coffee cultivation in North Toraja District, South Sulawesi, Indonesia. Biodiversitas 18 2017, pp,42-45

[12] Susanto A, Mujiyo, Purnomo D, Budiastuti MS. 2019. Peanut productivity under the albizia stand in agroforestry system. IOP Conf Ser Earth Environ Sci 2019, pp. 45-46. 